\title{
Sobre processos de apropriação e intersecção em imagens
}

On processes of appropriation and intersection in images

Sobre procesos de apropiación de intersección en imágenes

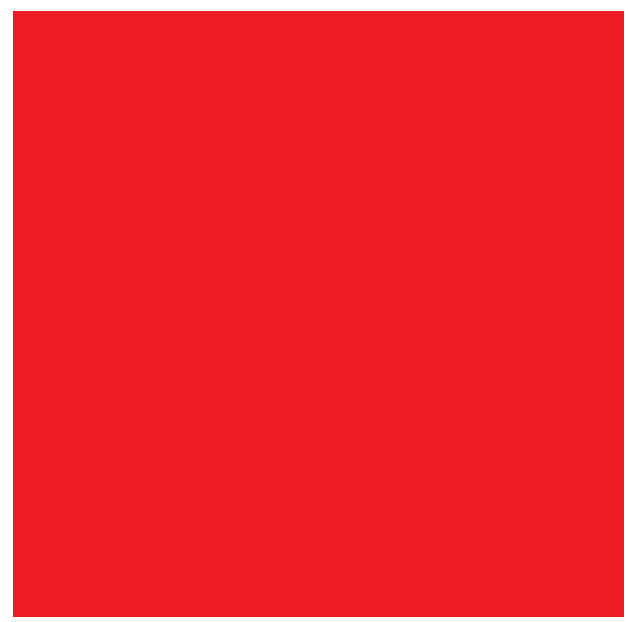

(a) Artista visual, fotógrafa e arte-educadora. Especialização em Poéticas Visuais na escola de Música e Belas Artes do Paraná (EMBAP). Enfance Centro de Modalidade de Educação Especial. Rua Paula Gomes, 864, São Francisco. Curitiba, PR, Brasil. 80510-070. cinribas@hotmail.com 
CRIAÇÃO

\section{Sobre processos de apropriação}

O final do século XIX demarca o fim da supremacia da Academia Tradicional de Arte, este derrame é pontual no que diz respeito ao sistema da Arte. Artistas, em contraste com a Academia, buscavam a autonomia de sua produção. As vanguardas surgiram embaladas pelo consumismo efervescente da nova sociedade moderna, capitalista e sedenta por inovação, transgredindo e reformulando práticas artísticas e seus modos de vivenciá-las. Uma destas práticas, das quais desejo conspirar no texto é a Apropriação, que em seu sentido direto quer dizer, tomar algo como próprio, tornar seu uma coisa alheia. O artista toma para si imagens, objetos, espaços e torna claro em sua produção esse desvio, conservando a identidade da coisa apropriada, criando diálogo em campo miscigenado pelo desdobramento de ambas as reproduções, por esta análise aponta Bourriaud ${ }^{1}$ em trecho da Estética Relacional, para o autor, o espectador completa a obra ao participar da elaboração de seu sentido:

Pode-se dizer que esses artistas que inserem seu trabalho no dos outros contribuem para abolir a distinção tradicional entre produção e consumo, criação e cópia, ready-made e obra original. Já não lidam com uma matéria-prima. Para eles, não se trata de elaborar uma forma a partir de um material bruto, e sim de trabalhar com objetos atuais em circulação no mercado cultural, isto é, que já possuem forma dada por outros. (p. 8)

Bourriaud ${ }^{1}$ utiliza em seus escritos, o termo pós-produção para designar as manifestações artísticas contemporâneas. Para ele, a apropriação é a primeira fase da pós-produção: não se trata mais de fabricar um objeto, mas de escolher entre os objetos existentes e utilizar ou modificar o item escolhido segundo uma intenção específica.

As manifestações de uma geração "sem-lugar", imprimem na produção artística seu contexto sóciopolítico-econômico. Marcados pelo pós-guerra e pela dissolução da fronteira entre arte e vida, de que maneira definir a partir daí o objeto como obra de arte.

É provável que a teoria do desvio esteja implicada pelos aspectos situacionistas. Talvez isso inscreva o sentido de bancar a subjetividade enquanto elemento difusor. Um signo novo ressurgia e os significados incorporados difundiam a poética dos artistas, o trabalho e as idéias. A questão da obra não se encontrava mais posta no visível ou mediante a estética da forma, mas no caráter ontológico aí inscrito, assim propõe Arthur Danto²:

Toda arte deve ter um significado, toda arte é representacional [...], sendo o formalismo inadequado como filosofia de arte. (p. 19) 


\section{Proposições:}

- 2013 Registros de Paisagem Coletiva “caixa d'água" Museu da Fotografia de Curitiba, exposição (19 de junho a 18 de agosto de 2013) Cintia Ribas em parceria de Fabio Noronha, Juliana Gisi e Gabriele Gomes.

\section{- 2013 "Corpos de Passagem" - Ação}

Performática em parceria de Mariana Barros, Daniel Valenzuela e Thiago Ramalho (áudio) durante projeção de imagens em Festival Fora da Forma de Curitiba - produção de Wake Up Colab.

- 2012 quando não mais - ADUAS, em parceria de Eliana Borges, em Museu Alfredo Andersen - 2012 el río en mí - ADUAS, em parceria de Eliana Borges e Ricardo Corona, agosto Galeria Sesc da Esquina.

- 2011 Novas Miradas Museu da Fotografia Coletiva MOB011, em parceria de Alexandre Zampier - 2011 ENCANTA_RIA - SESC da Esquina Projeto "Sim_Constante"

http://mostraencantaria.wordpress.com, em parceria de Constance Pinheiro.

- 2009 Itaúba - exposição fotográfica + instalação em parceria de Fernando Rosenbaum

\section{Atuação profissional:}

- Especialização em Poéticas Visuais Escola de Música e Belas Artes do Paraná. Monografia: "Sobre Processos de Apropriação e Intersecções em Imagens" - EMBAP/2014.

\section{Produções, integrações coletivas:}

- Workshop Produção Crítica em Artes Visuais, ministrada por Ana Luisa Lima e Clarissa Diniz set/ out de 2010.

- PIC Pesquisa de Iniciação Científica em fotografia e o sentido auto-etnológico vivenciado em viagens pelo observador-fotógrafo; Projeto intitulado "Entre Estranho \& Estrangeiro", orientação Profa. Dra. Ana Lucia Vásquez e apoio Fundação Araucária/ EMBAP. < http://aderivadoolhar.wordpress.com> - Monografia na Graduação: "A Fotografia vinculada a Registros e Processos de Viagem", orientação Prof. Dr. Fabio Noronha/ EMBAP 2011.

\section{Últimas exposições:}

- Instâncias e Entidades (sessões de projeção de vídeo e de fotografias) 15 de fev a 16 de março de 2013 em Bicicletaria Cultural de Curitiba em parceria de Gabriel Guerrer e Mariangela Quarentei.

- Mostra de Iniciação à Pesquisa Científica em Arte

- Galeria da Embap/junho 2012 imagem em retroprojetor.

- Coletiva" Chamando Vento" Espaço Tardanza participação na produção de dois vídeo performance e instalações work in progress com Eliana Borges, Constance Pinheiro, Janete Anderman e Maria Baptista. projeção de vídeo performance. espacotardanza.wordpress.com

- Coletiva "Cada qual com o seu Como" - BRDE Palacete dos Leões/janeiro de 2012 - foto-colagens individuais.

- Coletiva "Produção Oito-Onze" coletiva galeria da EMBAP abril de 2012 - projeção de imagem via projetor.

\section{Referências}

1. Bourriaud N. Estética relacional. Coleção todas as artes. São Paulo: Martins; 2009.

2. Danto AC. A transfiguração do lugar-comum: uma filosofia da arte. Trad. Vera Pereira. São Paulo: Cosac Naify; 2005. 

Cintia Ribas, Colagem, 2013 "Almanaque para entrevistar surrealismos". 


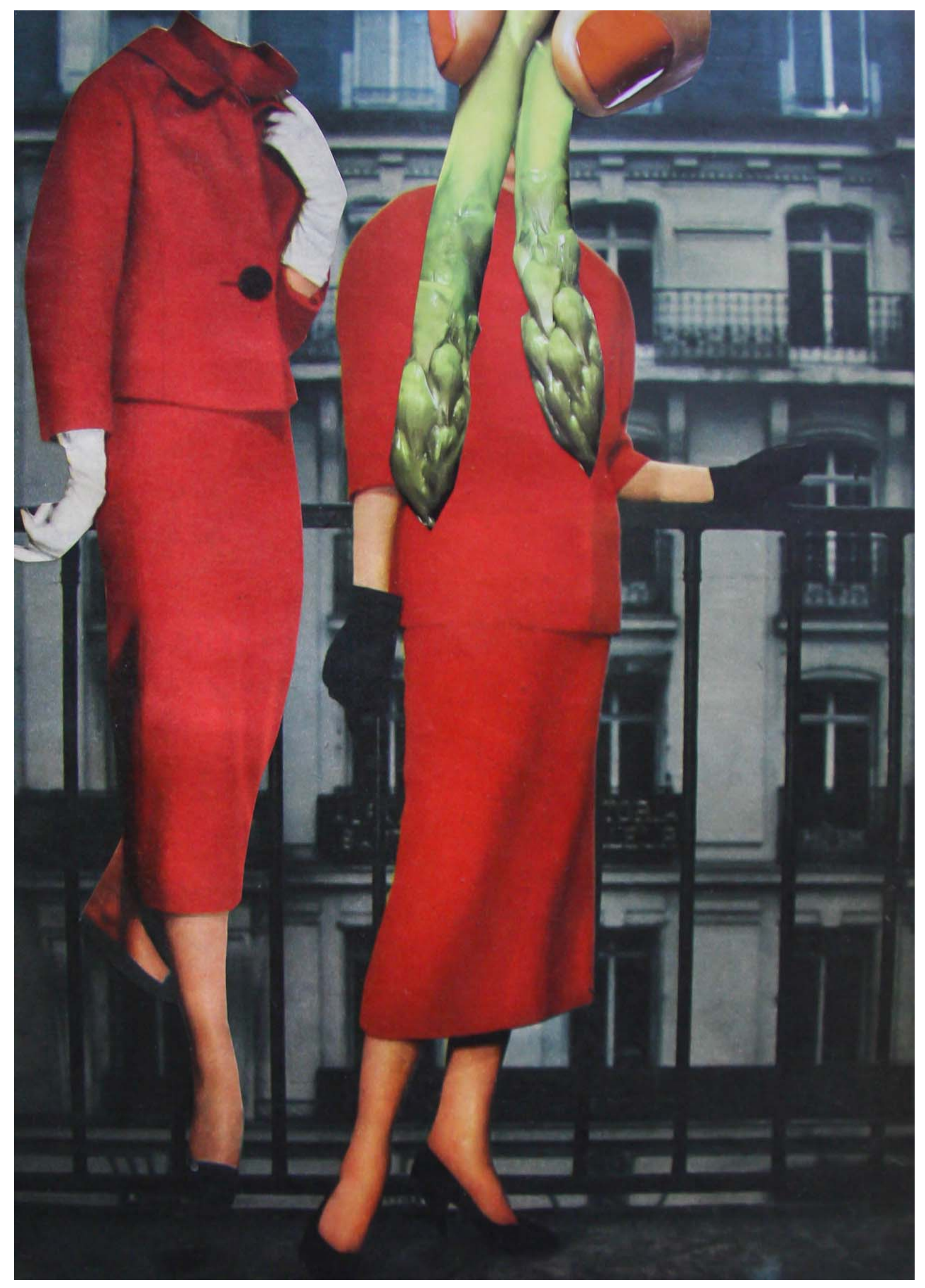


Cintia Ribas, Colagem, 2013 "Almanaque para entrevistar surrealismos". 


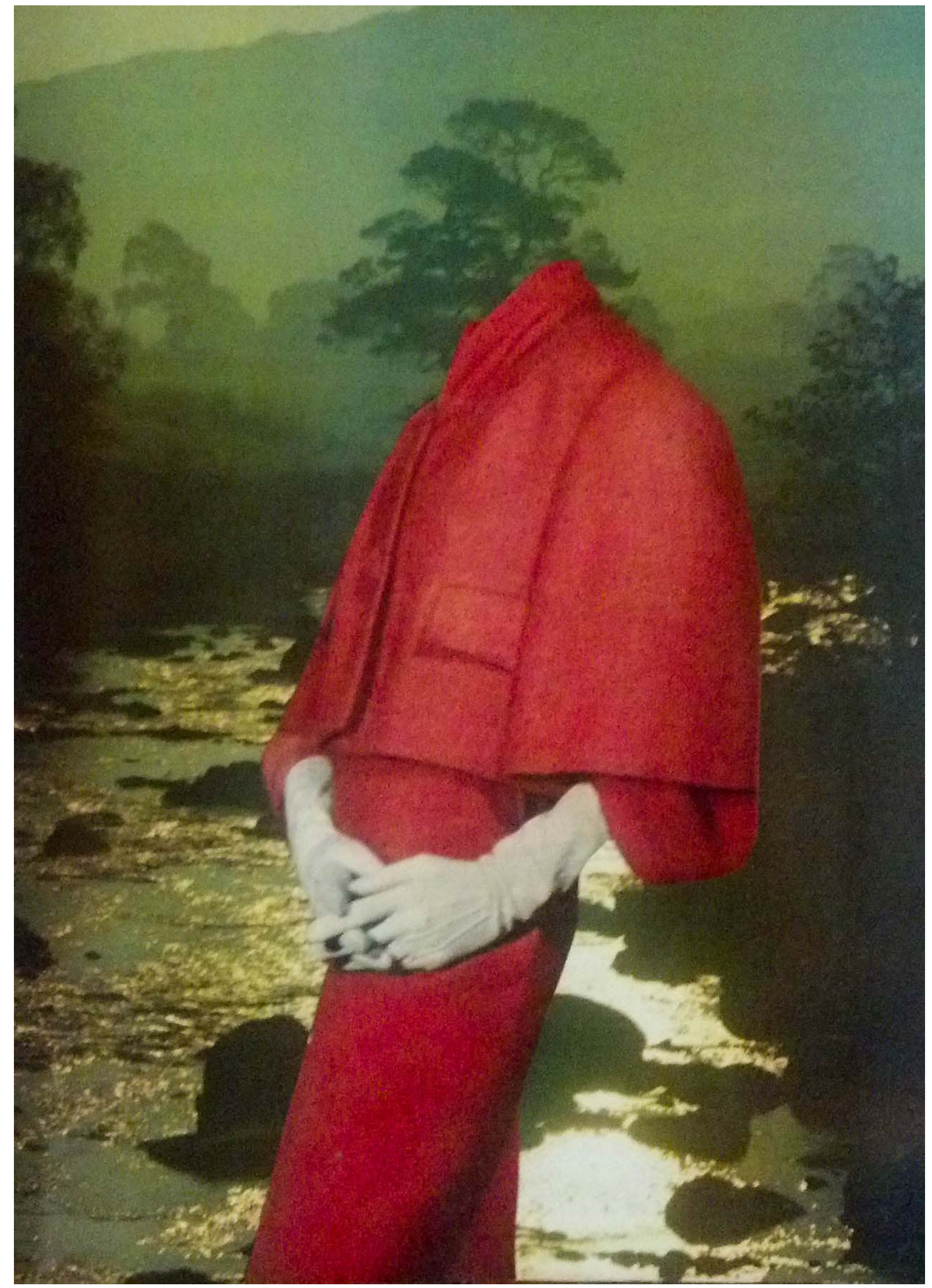


Cintia Ribas, Colagem, 2013 "Almanaque para entrevistar surrealismos". 


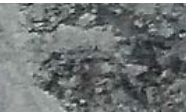

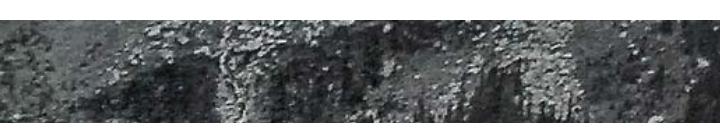
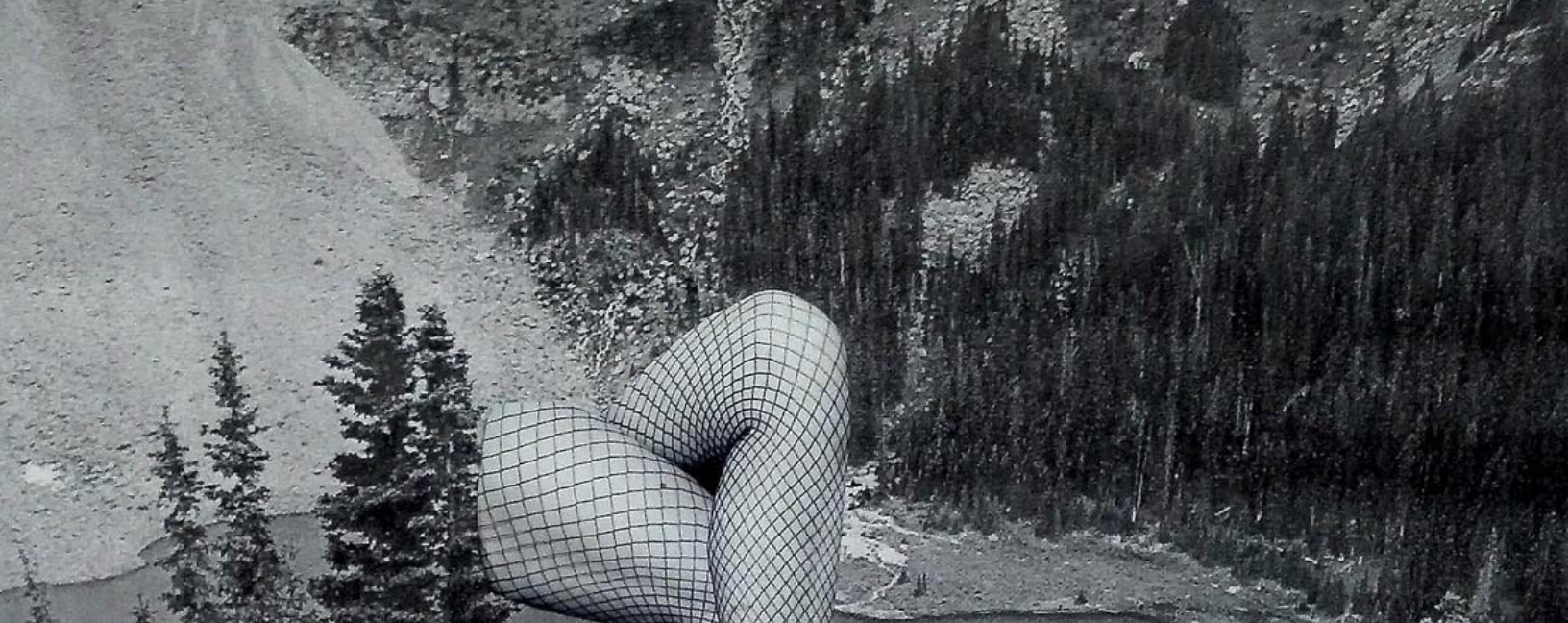

$3 x^{3}+x^{2}+x^{2}+n^{2}$ 6. 30,2

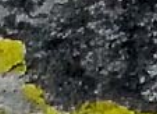

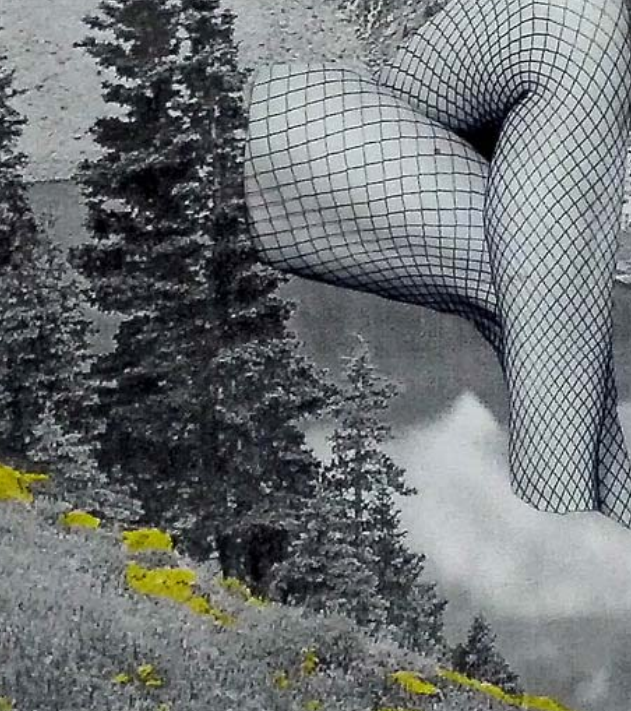

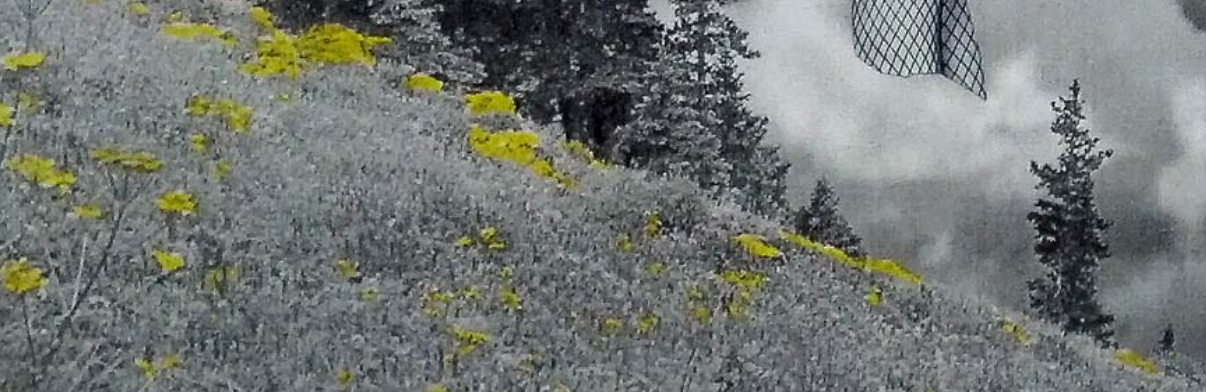

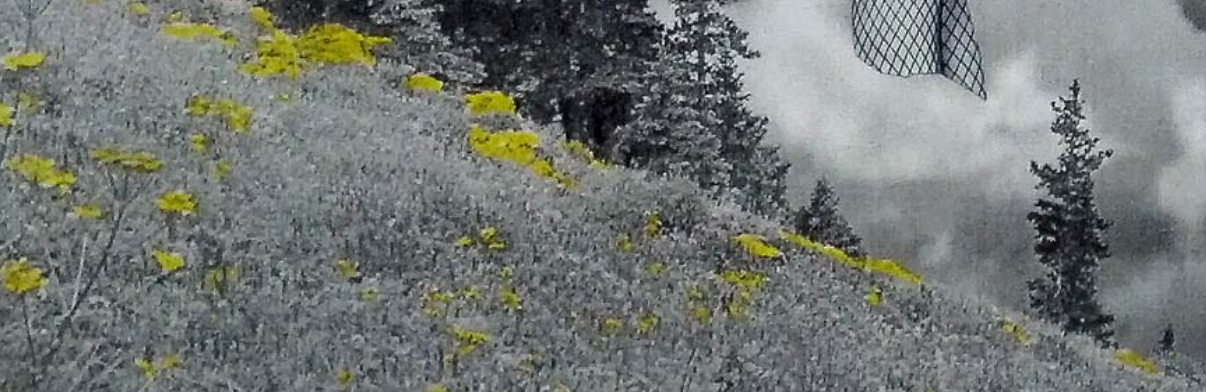
-

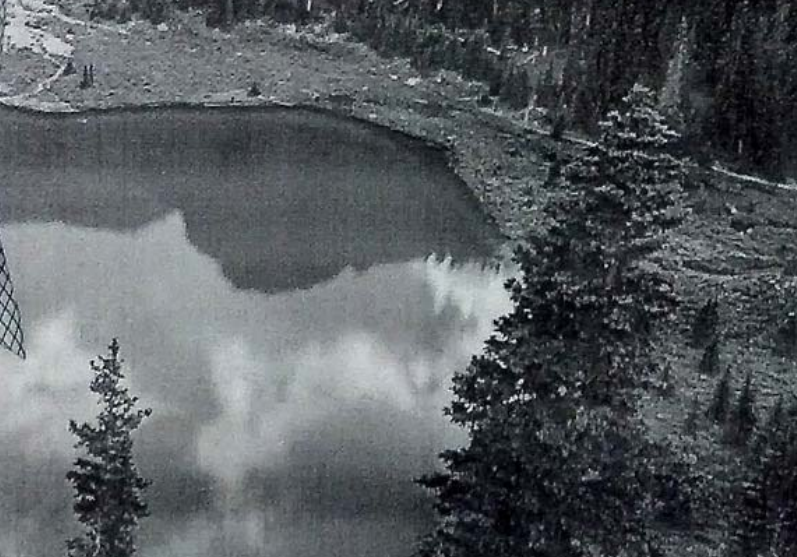
(5) ait $y$ in $2 x=2$

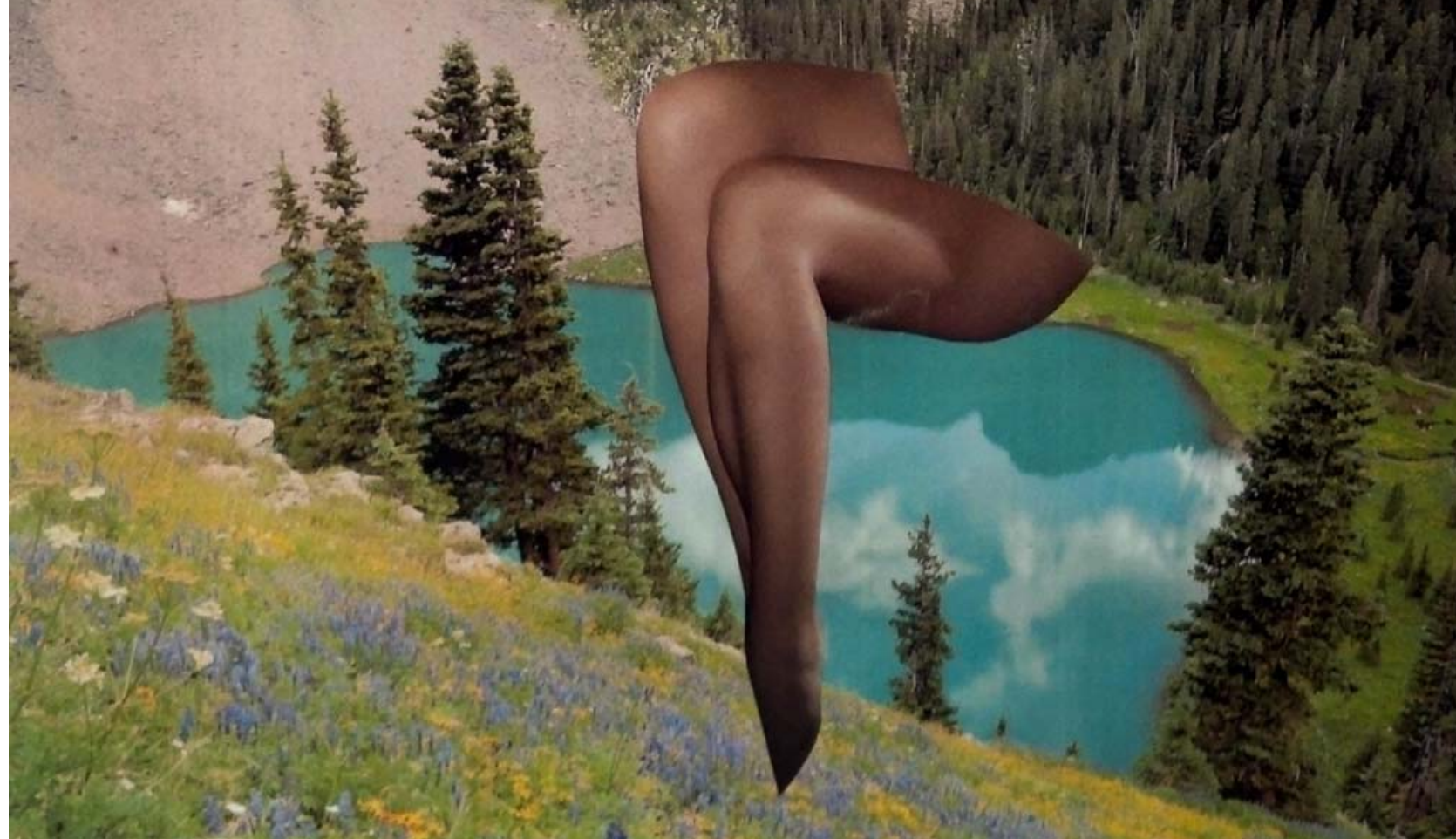


Cintia Ribas, Colagem, 2013 "série pernas" 
Tivel, wit?

monting

ᄀᄀ

$<\geqslant$ ists

- 1 (1) $1>1$

Lintisis

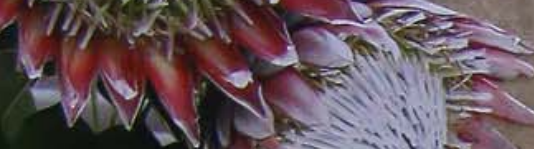

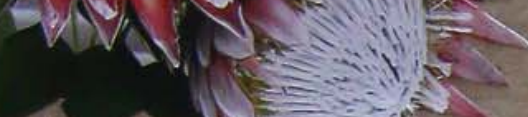
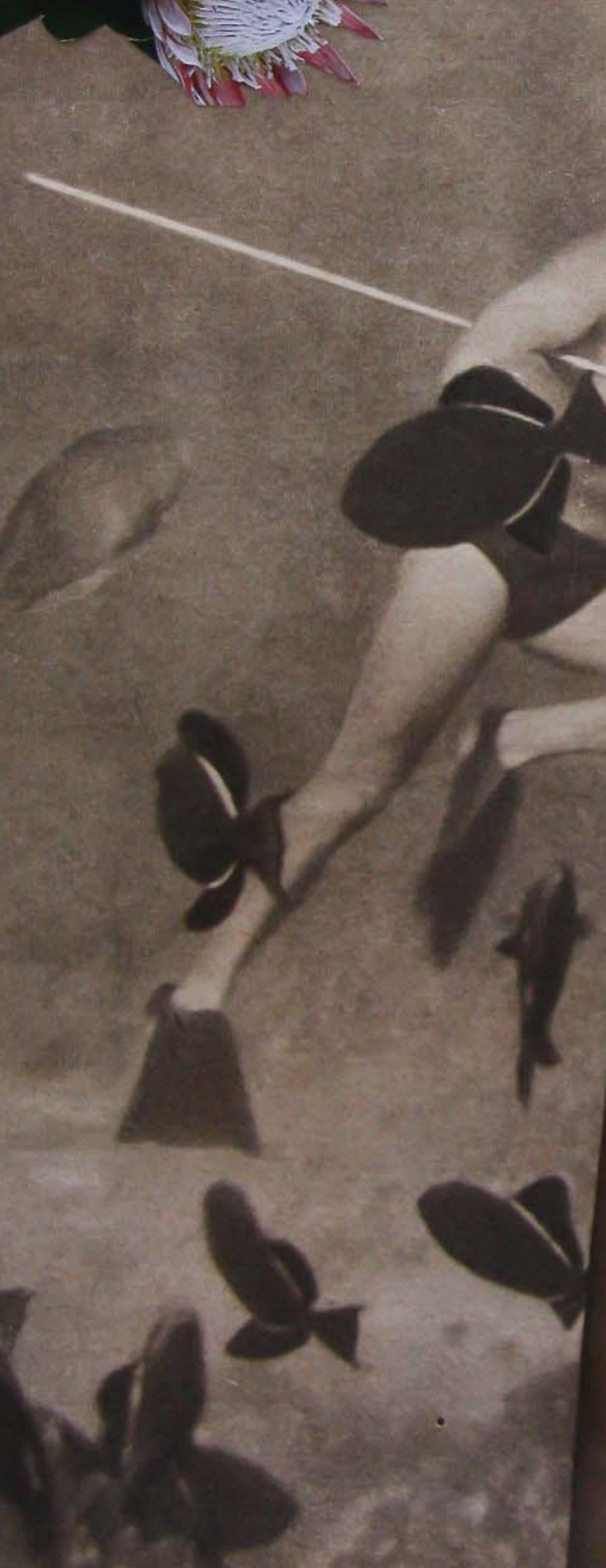

- $1(x)$

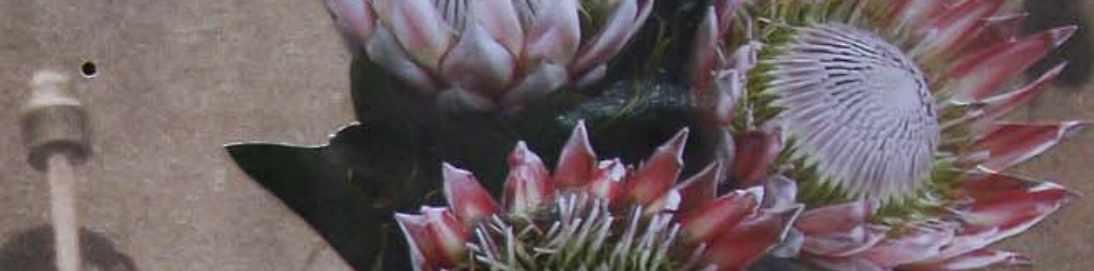

Tivilution

r.

$1-1,1>$

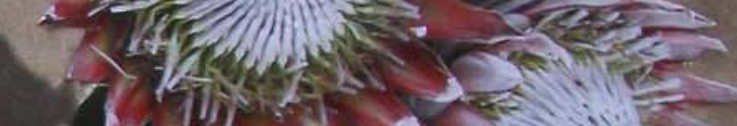

a $1, \ldots, \ldots$

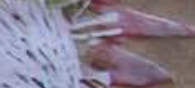

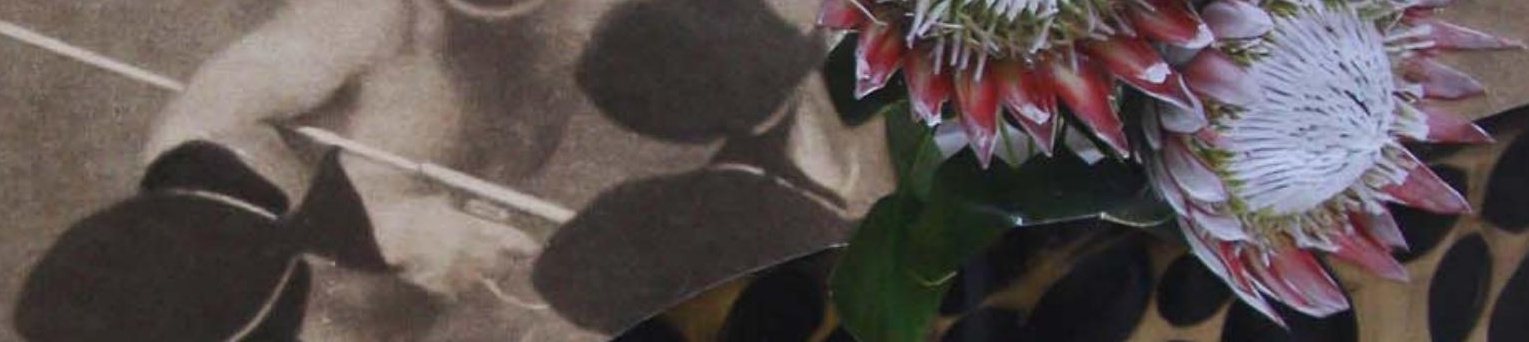

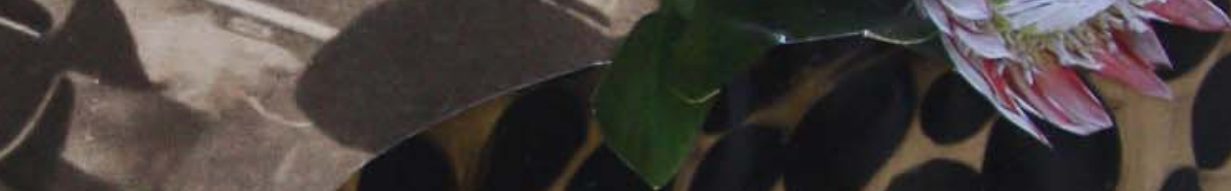

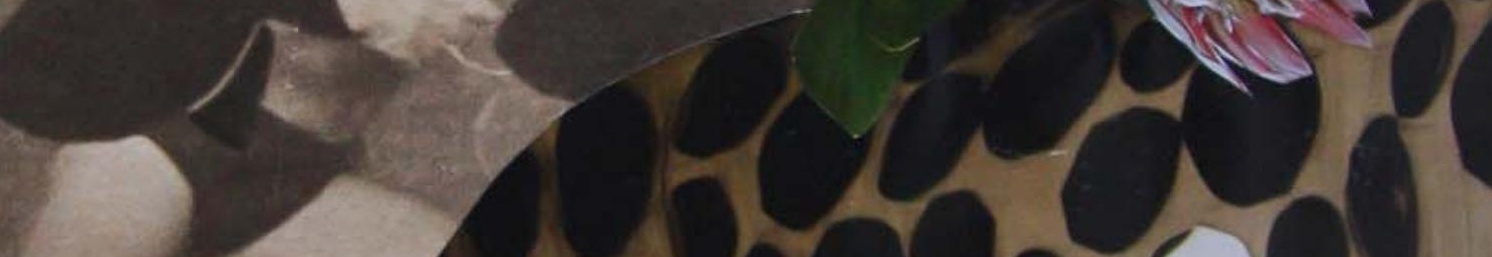


Cintia Ribas, Colagem, 2013 "Mergulhos para busca de". 


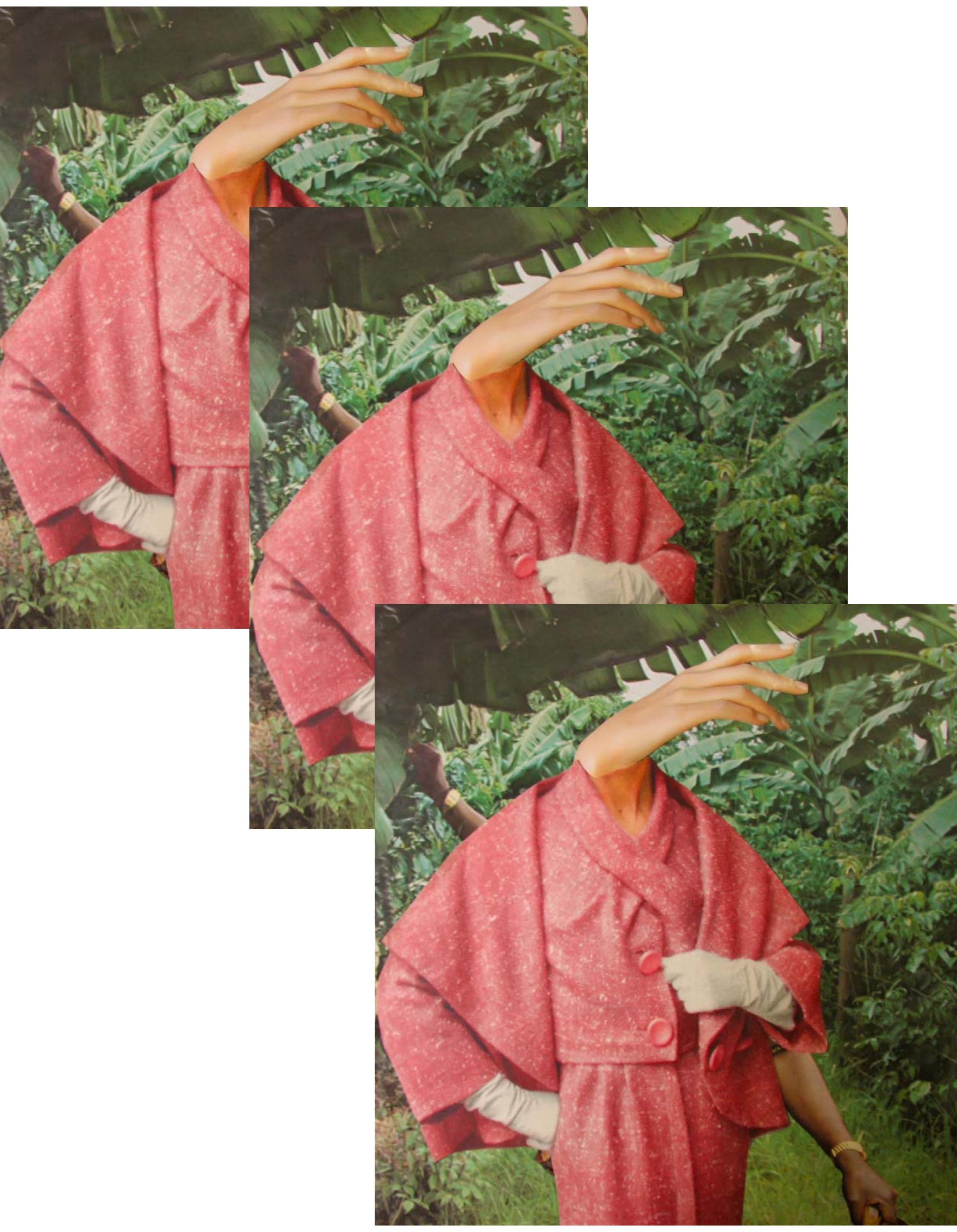


Cintia Ribas, Colagem, 2013 "Almanaque para entrevistar surrealismos". 